\title{
Systemic Epstein-Barr virus-positive T-cell lymphoproliferative disease of childhood
}

INSERM

\section{Source}

INSERM. (1999). Orphanet: an online rare disease and orphan drug data base. Systemic Epstein-Barr virus-positive T-cell lymphoproliferative disease of childhood. ORPHA:364033

Systemic Epstein-Barr virus (EBV)-positive T-cell lymphoproliferative disease of childhood is a rare and very aggressive neoplastic disease emerging after a primary acute or chronic active EBV infection. It presents with persisting fever and malaise, hepatosplenomegaly with or without lymphadenopathy, liver failure, severe pancytopenia and a rapid progression towards multi-org an failure and hemophag ocytic syndrome with a fatal issue. It is characterized by clonal proliferation of EBV-infected T cells with an activated cytotoxic phenotype. 